Journal of the Operations Research

Society of Japan

Vol. 22, No. 1, March, 1979

\title{
PERISHABLE INVENTORY PROBLEM WITH TWO TYPES OF WAREHOUSES
}

\author{
Junichi Nakagami \\ Chiba University
}

(Received April 17, 1978)

\begin{abstract}
This note considers the dynamic inventory problem in which the perishable product is to be stored in two types of warehouses. The problem is that how much amount of the product is ordered and preserved subject to the future demands. Hence the optimal ordering and preserving policies are obtained recursively with structural properties of the solution. Also the infinite horizon case is derived.
\end{abstract}

\section{Introduction}

The perishability of products is beginning to receive attention in the inventory problem. One important aspect of it is that the perishable products have a fixed life time and become useless to satisfy demands after a fixed length of periods (i.e., expiration date). Photographic films and drugs are common examples. Several authors investigated the model in which the products perish exactly $m$ periods after receipt on order. And they derived optimal ordering policies by solving a dynamic program with a state variable of dimension $m-1$, and also derived some qualitative properties of policies. See Fries [2], Nahmias and Pierskalla [4], [5] and Nahmias [6]. The structure of the optimal policies was significantly complex except $m=2$, then approximations were also derived. See Cohen [1] and Nahmias [7].

Another remarkable aspect of the perishability is that one can preserve the perishable products in a special equipment, which keeps them in the almost same quality and extends their life time for a pretty long period. For example, perishable foodstuffs like fresh fish and meat deteriorate in a week when refrigerated. But they will keep for half an year when frozen, which for the practical purpose is nonperishable. 
Now we make a model of the above as follows:

A preservable warehouse and an ordinary one are two types of warehouses, in which perishable products are to be stored. While the products in the former have an infinite life time as long as they are in, the products in the latter have a life time of one period so that they deteriorate at the end of the period. Also costs are incurred to the products in the former. In this situation, one must determine how much amount of the products is ordered and how much amount is stored in the preservable warehouse, subject to the demand at each period. Therefore, our purpose is to analyze this realistic model in order to derive an optimal preserving policy as well as an ordering one with their properties.

\section{Model}

We assume that time is divided into discrete periods that are numbered backwards from the planning horizon. Within each period the following events and decisions occur sequentially. Let a state variable $x$ be the amount of perishable products stored in the preservable warehouse, which was brought into this period. Now observing $x$, two decisions are made. So the amount $z-x$ is ordered and delivered immediately at unit ordering cost $c$ in order to raise the inventory level upto $z$. And the amount $y$ is stored in the preservable warehouse at unit preserving cost $h_{1}$, the amount $z-y$ is placed in the ordinary warehouse. The decision variables $y$, $z$ represent the starting amount of preserving inventory and the starting amount of the total inventory, respectively $(0 \leq x \leq z, 0 \leq y \leq z)$.

The demands in each period are independent and identically distributed nonnegative random variables with a distribution function $F$ and its density f. The inventory is first depleted from the ordinary warehouse, and depleted from the preserving one at unit emergency issuing cost $k_{2}$. The unsatisfied demand is lost for sales at unit penalty cost $p$. When the demand is over at the period, the amount remaining in the ordinary is disposed, and the amount remaining in the preserving is brought to the next period at unit holding cost $h_{2}$

Let a random variable $D$ represent a demand in the period. Then an amount $H$ remaining in the preserving and an amount $K$ issued from the preserving are given by

$$
H=\left(z-(z-y) V_{D}\right)^{+}, \quad K=\left(D_{\Lambda} z-(z-y)\right)^{+}
$$


This can be seen most easily by considering the three possibilities $0 \leqq D \leq z-y$, $z-y \leq D \leq z$ and $z \leq D$ separately, where $x^{+}=\max (0, x), x^{\vee} y=\max (x, y)$ and $x_{\wedge} y=$ $\min (x, y)$.

The following cost structure in the period is summarized:

$$
\begin{array}{ll}
c(z-x)^{+}=\text {ordering cost; } & h_{1} y=\text { preserving cost } \\
h_{2} H=\text { holding cost; } & k_{2} K=\text { issuing cost; } \\
p(D-z)^{+}=\text {penalty cost; } &
\end{array}
$$

Now, $H+K=y$, the preserving cost is included to the holding and issuing costs by putting $h=h_{1}+h_{2}, k=h_{1}+k_{2}$ respectively.

The problem is to characterize the ordering and preserving decision procedures which minimize the expected value of total costs given by the usual recursive equation in dynamic programming. Before the formulation, we examine random variables $H$ and $K$ without proof.

Lemma. The random variables $H$ and $K$ have distribution functions $H_{y_{g}}(\cdot)$ and $K_{y, z}(\cdot),(0 \leq y \leq z)$, respectively given by

$$
\begin{aligned}
H_{y_{9} z}(t) \equiv P[H \leq t] & =1-F(z-t) & & (0 \leq t<y) \\
& =1 & & (y \leqq t), \\
K_{y, z}(t) \equiv P[K \leqq t] & =F(z-y+t) & & (0 \leqq t<y) \\
& =1 & & (y \leqq t) .
\end{aligned}
$$

Moreover, if the density $f$ of $F$ is continuous and any given function $g$ is continuously differentiable over $[0, \infty)$, then

$$
H(y, z) \equiv \int_{0_{-}}^{\infty} g(t) d H_{y_{,},}(t), \quad K(y, z) \equiv \int_{0_{-}}^{\infty} g(t) d K_{y, z}(t)
$$

have partial derivatives.

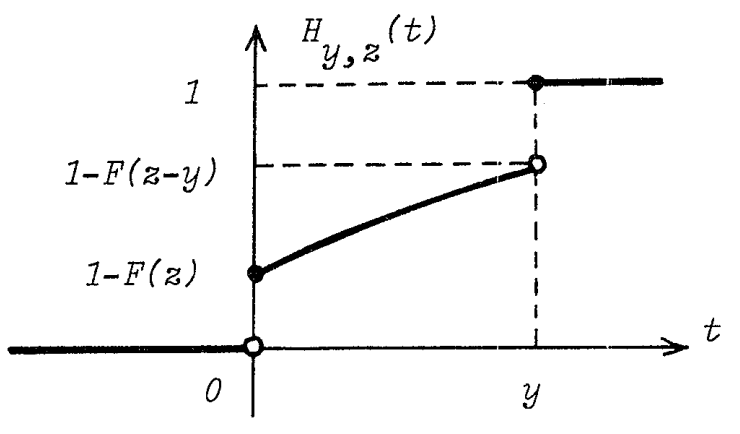

Fig. 1. Graph of $H_{y, z}(t)$

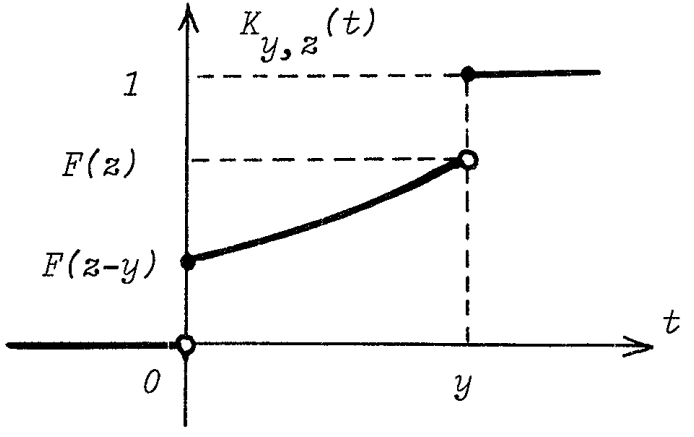

Fig. 2. Graph of $K_{y_{0} z}(t)$ 


\section{Formulation}

As usual, let $f_{n}(x)$ be the minimum expected cost over $n$ periods as a function of the level $x$ of preserving inventory before ordering. The principle of optimality for this problem takes the following form.

$$
\begin{aligned}
C_{n}(x)=\min _{z>x, z \geq y \geq 0}\left[B_{n}(y, z)-c x\right], \\
B_{n}(y, z)=c z+\int_{0_{-}}^{\infty} p(t-z)^{+} d F(t)+\int_{0-}^{\infty} k t d K_{y, z}(t) \\
+\int_{0_{-}}^{\infty}\left(h t+C_{n-1}(t)\right) d H_{y, z}(t), \quad\left(n=1,2, \cdots ; C_{0}(x)=0\right) .
\end{aligned}
$$

Let $y_{n}^{*}(x)$ and $z_{n}^{*}(x)$ denote the optimal preserving and ordering policies in the period $n$ when the injtial level of preserving inventory before ordering is $x$. We have

$$
C_{n}(x)=B_{n}\left(y_{n}^{*}(x), z_{n}^{*}(x)\right)-c x
$$

Then the purpose of the next theorems will be to demonstrate the existence of $y_{n}^{*}(x)$ and $z_{n}^{*}(x)$ and to derive some of their properties.

\section{Assumption .}

(A) $f(t)$ is continuous for all $t \geq 0$. (It is necessary for the lemma.)

( $\left.A^{\prime}\right) f(t)>0$ for all $t \geq 0$. (It is not always necessary but only for the uniqueness of solutions.)

(B) $c>h+k, p>c+h+k$. (It would be optimal to order and preserve the products at least.)

Theorem 1. Under the assumption, there exists a sequence $\left\{\bar{z}_{n}\right\}$ such that

$$
F^{-1}\left(\frac{p-c}{p}\right) \equiv \bar{z}_{1}<\bar{z}_{2}<\cdots<\bar{z}^{-1} \equiv F^{-1}\left(\frac{p-c-k}{p-c-k+h}\right) \text {. }
$$

If $\bar{z}_{n_{0}}=\bar{z}$ for some $n_{0}$, then $\bar{z}_{n_{0}}=\bar{z}_{n_{0}+1}=\cdots=\bar{z}$.

(I-1) Results on $C_{n}(x)$.

$C_{n}(x)$ is convex on $[0, \infty)$, and strictly convex on $\left[\bar{z}_{n}, \infty\right)$.

$C_{n}(x)$ is nonincreasing and nonnegative.

(1-2) Results on $C_{n}^{\prime}(x)$.

$C_{n}^{\prime}(x)$ in continuous and nondecreasing.

$C_{n}^{\prime}(x)=-c$ on $\left[0, \bar{z}_{n}\right] \cdot \lim _{x \rightarrow \infty} C_{n}^{\prime}(x)=0$. 
(1-3) Results on $y_{n}^{*}(x)$ and $z_{n}^{*}(x)$.

$z_{n}^{*}(x)=\bar{z}_{n} \vee x, \quad y_{n}^{*}(x)=\bar{y}_{n}\left(\bar{z}_{n} \vee_{x}\right)$. Where $\bar{y}_{n}(x)$ is a unique solution $y$ to $k+\left(h-k-C_{n-1}(y)\right) F(x-y)=0$ for all $x \geqq \bar{y} \equiv F^{-1}\left(\frac{k}{c-h-k}\right)$,

specially $\bar{y}_{1}(x)=0, \bar{y}_{n}\left(\bar{z}_{n}\right)=\bar{z}_{n}-\bar{y}(n=2,3, \cdots)$.

$0 \leqq \frac{d y_{n}^{*}(x)}{d x} \leqq 1, y_{n}^{*}(x)$ is bounded for ail $x \geqq 0$.

Theorem 2.

(2-1) $\quad C_{n+1}(x) \geqq C_{n}(x), \quad C_{n+1}^{\prime}(x) \leqq C_{n}^{\prime}(x) \quad(n=0,1,2, \cdots)$ for all $x \geqq 0$.

$(2-1) \quad \bar{y}_{n+1}(x) \geqq \bar{y}_{n}(x) \quad(n=1,2, \cdots)$ for all $x \geqq \bar{y}$.

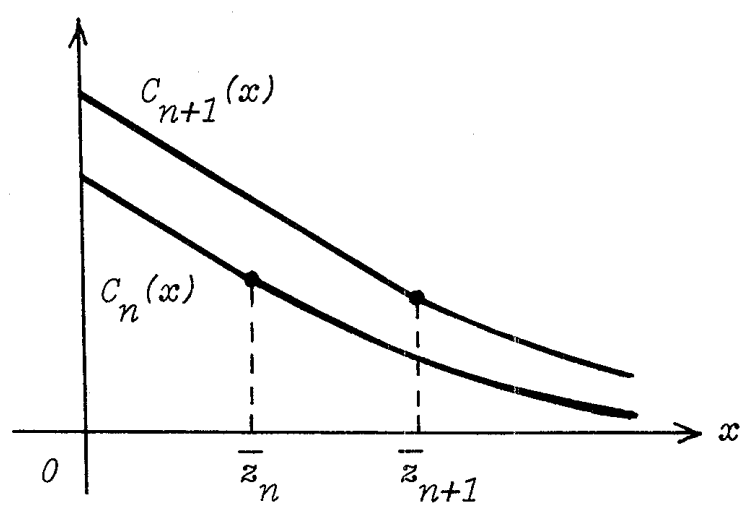

Fig. 3. Graph of $C_{n}(x)$

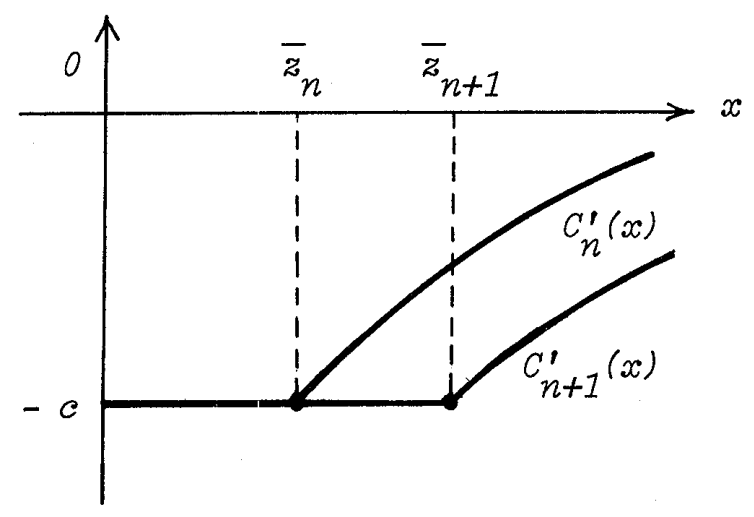

Fig. 4. Graph of $C_{n}^{\prime}(x)$

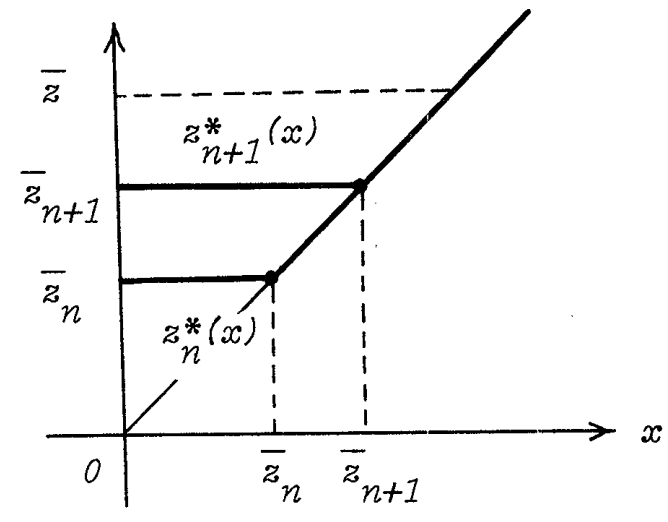

Fig. 5. Graph of $z_{n}^{*}(x)$

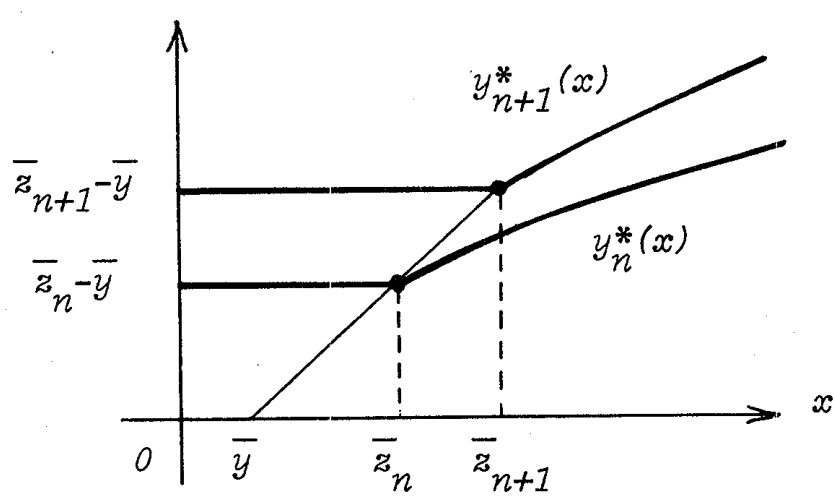

Fig. 6. Graph of $y_{n}^{*}(x)$ 
The theorems reveal some structual properties of the minimum expected cost $C_{n}(x)$ by the fig. 3,4 and the optimal policies by the fig. 5,6, respectively. Now we interpret the optimal ordering policy $z_{n}^{*}(x)$ and the optimal preserving policy $y_{n}^{*}(x)$ as follows:

(7) If $x<\bar{z}_{n}$, it is optimal to order the amount $\bar{z}_{n}-x$ so as to raise the total inventory upto $\bar{z}_{n}$. It is optimal to preserve the amount $\bar{z}_{n}-\bar{y}$ in the preserving and to place the amount $\bar{y}$ in the ordinary when $n=2,3, \cdots$ : Or to preserve none of the amount and to place all the amount $\bar{z}_{1}$ in the ordinary when only $n=1$. Note that the penalty cost $p$ depends only on the total inventory $\bar{z}_{n}$, but is independent of the amount $\bar{y}$ in the ordinary.

(8) If $x \geqq \bar{z}_{n}$, it is optimal to order none of the amount so as to keep the total inventory to $x$. It is optimal to preserve the amount $\bar{y}_{n}(x)$ in the preserving and to place the amount $x-\bar{y}_{n}(x)$ in the ordinary when $n=$ $2,3, \cdots:$ Or to preserve none of the amount and to place all the amount $x$ in the ordinary when only $n=1$. Note that the amount $\bar{y}_{n}(x)$ in the preserving is bounded. This indicates that the system is forced to go quickly to the steady state (7) when the initial level is sufficiently large.

Proof of the theorem 1. The proof is by induction. Assume the theorem is true for $1,2, \cdots, n-1$. The case of $n=1$ is easily established by calculating $(4),(5)$ in the almost same manner when $n$ is arbitary with $c_{0}(x)=0$.

$$
\begin{aligned}
B_{n}(y, z)= & c z+\int_{0-}^{\infty} p(t-z)^{+} d F(t)+\int_{0-}^{\infty} k t d K_{y, z}(t) \\
& +\int_{0-}^{\infty}\left(h t+C_{n-1}(t)\right) d H_{y, z}(t) . \\
\frac{\partial B_{n}(y, z)}{\partial y} & =k+\left(C_{n-1}^{\prime}(y)+h-k\right) F(z-y) . \\
\frac{\partial^{2} B_{n}(y, z)}{\partial y^{2}} & =C_{n-1}^{\prime \prime}(y) F(z-y)+\left(k-h-C_{n-1}^{\prime}(y)\right) f(z-y) .
\end{aligned}
$$

(i) First, we consider $y_{n}^{*}(z)$ which would minimize $B_{n}(y, z)$ on $[0, z]$ for any fixed $z$. By the inductive assumption on (1-2), the point $y_{h}$ which satisfies $C_{n-1}^{\prime}(y)=-h$ is bounded. And,

$$
C_{n-1}^{\prime}(y)>-h, \frac{\partial B_{n}(y, z)}{\partial y}>k(1-F(z-y)) \geqq 0 \text { on }\left(y_{h}, \infty\right) .
$$

Then, $y_{n}^{*}(z)$ would be in the interval $\left[0, z \wedge y_{h}\right]$. And 


$$
C_{n-1}^{\prime}(y) \leqq-h, \frac{\partial^{2} B_{n}(y, z)}{\partial y^{2}} \geq C_{n-1}^{\prime \prime}(y) F(z-y)+k f(z-y)>0 \quad \text { on }\left[0, z_{\wedge} y_{h}\right] .
$$

Since $B_{n}(y, z)$ is strictly convex in $y$ on $\left[0, z, y_{h}\right]$ for any fixed $z, y_{n}^{*}(z)$ is the smallest value $y$ of

$$
\frac{\partial B_{n}(y, z)}{\partial y}=k+\left(h-k+C_{n-1}^{\prime}(y)\right) F(z-y) \geqq 0 \text {. }
$$

That is, if $z \leqq \bar{y} \equiv F^{-1}\left(\frac{k}{c-h+k}\right)$ then $y_{n}^{*}(z)=0$, and if $z \geqq \bar{y}$ then $y_{n}^{*}(z)$ is the unique bounded solution $\bar{y}_{n}(z)$ which satisfies

$$
k+\left(h-k+C_{n-1}^{\prime}(y)\right) F(z-y)=0 .
$$

Note that $\bar{y} \equiv F^{-1}\left(\frac{k}{c-h+k}\right)<\bar{z}_{1} \equiv F^{-1}\left(\frac{p-c}{p}\right)$ by the assumption (B). Then $\bar{y}<\bar{z}_{n-1}$ is true by the inductive assumption.

$$
\bar{y}_{n}(z)=z-\bar{y} \text { on }\left[\bar{y}_{,}, \bar{z}_{n-1}\right] \text {. }
$$

Corollary. $0 \leqq \frac{d \bar{y}_{n}(z)}{d z} \leqq 1$ for $z \geqq \bar{y}$.

Proof. By the differentiation of (9) with respect to $z$, we obtain

$$
\frac{d \bar{y}_{n}(z)}{d z}=\frac{\left(k-h-C_{n-1}^{\prime}\left(\bar{y}_{n}\right)\right) f\left(z-\bar{y}_{n}\right)}{\left(k-n-C_{n-1}^{\prime}\left(\bar{y}_{n}\right)\right) f\left(z-\bar{y}_{n}\right)+C_{n-1}^{\prime \prime}\left(\bar{y}_{n}\right) F\left(z-\bar{y}_{n}\right)}
$$

Where $C_{n-1}^{\prime}\left(\bar{y}_{n}\right) \leqq-h$, which complete the proof of the corollary.

(ii) Second, we consider $\bar{z}_{n}$ which would minimize $B_{n}\left(y_{n}^{*}(z), z\right)$ for all $z \geqq 0$. Let $z \leqq \bar{y}$, then

$$
\begin{aligned}
& B_{n}\left(y_{n}^{*}(z), z\right)=B_{n}(0, z)=c z+\int_{0-}^{\infty} p(t-z)^{+} d F(t)+C_{n-1}(0) . \\
& \frac{d B_{n}}{d z}=(c-p)+p F(z) \cdot \frac{d^{2} B_{n}}{d z^{2}}=p f(z)>0 .
\end{aligned}
$$

If $z \geqq \vec{y}$, then

$$
\begin{aligned}
B_{n}\left(y_{n}^{*}(z), z\right) & =B_{n}\left(\bar{y}_{n}(z), z\right)=c z+\int_{0-}^{\infty} p(t-z){ }^{+} d E^{\prime}(t) \\
& +\int_{0-}^{\infty} k t d K_{\bar{y}_{n}, z}(t)+\int_{0_{-}}^{\infty}\left(h t+C_{n-1}(t)\right) d H_{\bar{y}_{n}}, z(t) .
\end{aligned}
$$


(11)

$$
\begin{aligned}
\frac{\partial B_{n}}{d z} & =c-p+p E^{\prime}(z)+\int_{z-\bar{y}_{n}}^{z}\left(h-k+C_{n-1}^{\prime}(z-t)\right) f(t) d t \\
& +\left\{k(1-F(z))+\int_{z-\bar{y}_{n}}^{z} k f(t) d t+\left(h+C_{n-1}^{\prime}\left(\bar{y}_{n}\right)\right) F\left(z-\bar{y}_{n}\right)\right\} \bar{y}_{n}^{\prime} .
\end{aligned}
$$

Where the term in brackets is zero by the definition (9) of $\bar{y}_{n}(z)$. Then

$$
\begin{aligned}
\frac{d^{2} B_{n}}{d z^{2}} & =(p+h-k-c) f(z)+\int_{z-\bar{y}_{n}}^{z} C_{n-1}^{\prime \prime}(z-t) f(t) d t \\
& +\left(k-h-C_{n-1}^{\prime}\left(\bar{y}_{n}\right)\right) f\left(z-\bar{y}_{n}\right)\left(1-\bar{y}_{n}^{\prime}\right)>0,
\end{aligned}
$$

by the inductive assumption on (1-1) and the corollary .

Now $B_{n}\left(y_{n}^{*}(z), z\right)$ is strictly convex for all $z \geqq 0$ by $(12)$, then $\bar{z}_{n}$ is the unique solution of $\frac{d B_{n}\left(y_{n}^{*}, z\right)}{d z}=0$.

$$
\begin{aligned}
\left.\frac{d B_{n}\left(y_{n}^{*}, z\right)}{d z}\right|_{z=\bar{z}_{n-1}} & =(c-p)+p F\left(\bar{z}_{n-1}\right)+\int_{\bar{y}}^{\bar{z}_{n-1}}(h-k-c) f(t) d t \text { by }(10) \\
& =(c-p+k)+(p+n-k-c) F\left(\bar{z}_{n-1}\right) .
\end{aligned}
$$

Since $\bar{z}_{1}<\bar{z} \equiv F^{-1}\left(\frac{p-c-k}{p-c-k+h}\right),(13)=0$ if $\bar{z}_{n-1}=\bar{z}$ and $(13)<0$ if $\bar{z}_{n-1}<\bar{z}$. That is, $\bar{z}_{n-1}=\bar{z}_{n}=\bar{z}$ or $\bar{z}_{n-1}<\bar{z}_{n} \leq \bar{z}$, which is the conclusion of the sequence $\left\{\bar{z}_{n}\right\}$.

Hence it is easily shown that $z_{n}^{*}(x)$ which minimize $B_{n}\left(y_{n}^{*}(z), z\right)$ on $[x, \infty)$ for any fixed $x$ is $\bar{z}_{n}^{v} x$. Then the optimal policies in the period $n$ when the initial level is $x$ are given by

$$
\begin{aligned}
& z_{n}^{*}(x)=\bar{z}_{n} \vee x, \\
& y_{n}^{*}(x) \equiv y_{n}^{*}\left(z_{n}^{*}(x)\right)=\bar{y}_{n}\left(\bar{z}_{n} \vee x\right),
\end{aligned}
$$

which complete the proof of (1-3).

(iii) Finally we express $C_{n}(x)$.

$$
\begin{aligned}
C_{n}(x) & =B_{n}\left(\bar{y}_{n}(x), x\right)-c x \\
& =\int_{0_{-}}^{\infty} p(t-x)+d F(t)+\int_{0_{-}}^{\infty} k t d K_{\bar{y}_{n}, x}(t) \\
& +\int_{0_{-}}^{\infty}\left(h t+C_{n-1}(t) d \bar{y}_{n}, x\right.
\end{aligned}
$$




$$
C_{n}(x)=B_{n}\left(\bar{z}_{n}-\bar{y}_{1}, \bar{z}_{n}\right)-c x \quad\left(x<\bar{z}_{n}\right) .
$$

By (12) the proof of (1-1) is completed. And we have

$$
\begin{aligned}
C_{n}^{\prime}(x) & =-c & \left(x<\bar{z}_{n}\right) . \\
& =-p(1-F(x))+\int_{x-\bar{y}_{n}}^{x}\left(n-k+C_{n-1}^{\prime}(x-t)\right) f(t) d t & \left(x \geq \bar{z}_{n}\right) .
\end{aligned}
$$

Since $-c \leqq C_{n-1}^{\prime}(x-t) \leqq-h$ for $x-t \varepsilon\left[0, \bar{y}_{n}\right]$, then

$$
\begin{aligned}
& -p(1-F(x))-(k+a-h)\left(F(x)-F\left(x-\bar{y}_{n}\right)\right) \leqq C_{n}^{\prime}(x) \leqq \\
& -p(1-F(x))-k\left(F(x)-F\left(x-\bar{y}_{n}\right)\right), \text { so that } \lim _{x \rightarrow \infty} C_{n}^{\prime}(x)=0
\end{aligned}
$$

from the boundness of $\bar{y}_{n}(x)$ by (9). Which complete the proof of (1-2).

Proof of the theorem 2. The proof is by induction. It is generaliy true by the recursive equation $(4),(5)$ that $C_{n+1}(x) \geqq C_{n}(x) \quad(n=0,1,2, \cdots)$ for all $x \geqq 0$, then we would show that $C_{n+1}^{\prime}(x) \leqq C_{n}^{\prime}(x) \quad(n=0,1,2, \cdots)$. Assume the result holds for $0,1,2, \cdots, n-1$, then the case of $n=0$ is easy, we prove it true for $n$.

$\bar{y}_{n}(x)$ for $x \geqq \bar{y}$ satisfies the following from (9),

$$
F\left(x-\bar{y}_{n}\right)=\frac{k}{-C_{n-1}^{\prime}\left(\bar{y}_{n}\right)-n+k} \geqq \frac{k}{-C_{n}^{\prime}\left(\bar{y}_{n}\right)-n+k} \quad \text { by } C_{n}^{\prime}\left(\bar{y}_{n}\right) \leqq C_{n-1}^{\prime}\left(\bar{y}_{n}\right) \leqq-n,
$$

also $\bar{y}_{n+1}(x)$ satisfies

$$
F\left(x-\bar{y}_{n+1}\right)=\frac{k}{-C_{n}^{\prime}\left(\bar{y}_{n+1}\right)-n+k}
$$

Which lead to $\bar{y}_{n}(x) \leqq \bar{y}_{n+1}(x)$ for $x \geqq \bar{y}$. Now from (15)

$$
\begin{aligned}
C_{n+1}^{\prime}(x)=-c \leqq C_{n}^{\prime}(x) \text { for } x<\bar{z}_{n+1} . \quad \text { If } x \geqq \bar{z}_{n+1}, \\
C_{n}^{\prime}(x)=-p(1-F(x))+\int_{x-\bar{y}_{n}}^{x}\left(h-k+C_{n-1}^{\prime}(x-t)\right) f(t) d t \\
\geq-p(1-F(x))+\int_{x-\bar{y}_{n+1}}^{x}\left(h-k+C_{n-1}^{\prime \prime}(x-t)\right) f(t) d t
\end{aligned}
$$

by the nonpositive integrand,

$$
\geqq-p(1-F(x))+\int_{x-\bar{y}_{n+1}}^{x}\left(h-k+c_{n}^{\prime}(x-t)\right) f(t) d t=c_{n+1}^{\prime}(x) \text {. }
$$




\section{Special case \& Stationary analys is}

In this section we examine the stationary policies of our inventory problem with two special cases. First we obtain the nonperishable case by putting $z=y$ in $(4),(5)$.

$$
\begin{aligned}
& C_{n}^{\infty}(x)= \min _{y \geq x}\left[c(y-x)+\int_{0-}^{\infty} p(t-y)^{+} d F(t)+\int_{0-}^{\infty} k\left(t_{n} y\right) d F(t)\right. \\
&+\left.\int_{0_{-}}^{\infty} h(y-t)^{+} d F(t)+\int_{0-}^{\infty} C_{n-1}^{\infty}\left((y-t)^{+}\right) d F(t)\right] \\
&\left(n=1,2, \cdots ; C_{0}^{\infty}(x)=0\right) .
\end{aligned}
$$

On the other hand, we also obtain the one-period perishable case by putting $y=x=0$ in (4), (5).

$$
\begin{aligned}
C_{n}^{1}(0)=\min _{z>0}\left[c z+\int_{0-}^{\infty} p(t-y)^{+} d F(t)\right. & \left.+c_{n-1}^{1}(0)\right] \\
& \left(n=1,2, \cdots ; c_{0}^{1}(x)=0\right) .
\end{aligned}
$$

Now, the optimal policy for our n-period problem $(4),(5)$ is determined by the critical numbers $\left\langle\bar{z}_{n}-\bar{y}_{,} \bar{z}_{n}\right\rangle$ when the initial level j.s less than $\bar{z}_{n}$. Then we consider the stationary distribution of the random variable $X_{n}$ that denotes the initial level before the decision is made at the period $n$, where the policy is determined by the critical numbers $\langle y, z\rangle$. We see that the stationary distribution function of $X_{n}$ is $H_{y, z}(\cdot)$ given by the lemma. This will be derived with the same argument given by the section 3 (Stationary Analysis) in Iglehart [3]. Then the average cost $A(y, z)$ wi.th respect to the stationary distribution is

$$
A(y, z)=c z+\int_{0_{-}}^{\infty} p(t-z)^{+} d F(t)+\int_{0_{-}}^{\infty} k t d k_{y, z}(t)+\int_{0_{-}}^{\infty}(h-c) t d H_{y, z}(t) .
$$

Hence we obtain that the minimum value of $\langle y, z\rangle$, call it $\langle\tilde{y}$, $\tilde{z}\rangle$, is $\langle\bar{z}-\bar{y}, \bar{z}\rangle$ by referring the proof of the theorem 1 . Also we obtain the minimum stationary policies $\tilde{y}^{\infty}, Z^{1}$ for the special case (16), (17), respectively, then $\tilde{y}^{\infty}=\bar{z}, \tilde{z}^{1}=\bar{z}_{1}$. Note that the same amount $\bar{z}$ is ordered on both problems, our problem (4), (5) and the nonperishable one (16), in the stationary case. And that the same amount $\bar{z}_{1}$ is ordered on both problems, our one-period case of (4), (5) and the one-period perishable problem (17). 


\section{References}

[I] Cohen, M. A.: Analysis of single critical number ordering policies for perishable inventories. Operations Research, Vol. 24, No. 4 (1976), 726-741.

[2] Fries, B, E.: Optimal ordering policies for a perishable commodity with fixed life time. Operations Research, Vol. 23, No. I (1975), 46-61.

[3] Iglehart, D. I.: Dynamic programing and stationary analysis of inventory problems. in Multistage Inventory Molel and Techniques, Stanf. Univ. Press (1963).

[4] Nahmias, S. and Pierskalla, W. P.: Optimal ordering policies for a product that perishes in two periods subject to stochastic demand. N.R.L.Q. Vol. 20 (1973), 207-229.

[5] - A two-product perishable/nonperishable inventory problem. SIAM. J. Appl. Math., Vol. 30, No. 3 (1976), 483-500.

[6] Nahmias, S.: Optimal ordering policies for a perishable inventory-II. Operations Resecoch, Vol. 23, No. 4 (1975), 735-749.

[7] - Myopic approximations for the perishable inventory problem. Monagement Science, Vol. 22, No. 9 (1976), 1002-1008.

Junichi NAKAGAMI: Department of Mathematics, Faculty of Science, Chiba University, 1-33 Yayoi-cho, Chiba-city, Japan. 
二種類の倉庫をもつ陳腐化する在庫問題

千渠大学 中 神 潤 一

最近，在庫問題の分野に括いて，陳腐化する品目（化学薬品，食料品など）を取り扱う文献が多数 見られる。これらの文献は，この品目の特徵の一つである，一定の寿命期間を過ぎると製品としての 価値がなくなってしまうという点に注目して，動的計画法を用いてモデル化を行なっている。したが って，期待費用を最小にする最適注文政策は初期在庫量と品目の年令の関数になり，この関数の定性 的な性質を調べることができる。

ここでは, 陳腐化する品目のもう一つの特徴である保存可能という点（例えば, 生鮮食料品などは 冷凍保存することによりその製品寿命を延ばすことができる。）に注目してモデル化を行う。すなわ ち, 製品を入れる倉庫には保存倉庫と普通倉庫の二種類があり，前者に入れられた品物は，入れられ ている限り品質に変化はな々寿命のとして次の期に繰り越され，後者に入れられたものは寿命一期間 としてその期の終わりに廃用となる。もちろん保存倉庫に入れられたるのには費用がかかるものとす る。したがって，このモデルにおいては，期待総費用を最小にするために，各期において注文と保存 の二つの決定をどのように行なったらよいかが問題となる。

本論文は，簡単のため線形な費用を仮定して定式化を行い，最適な注文政策 $\mathrm{z}_{\mathrm{a}}^{*}(\mathrm{x})$ ，保存政策 $\mathrm{y}_{\mathrm{a}}^{*}(\mathrm{x})$ を正確に求めるのを目的としている。一般にこれらは定水準政策になることが示されるが， 特に無限期間に打ける最適な定常政策はコスト ・パラメータだけで決まる。 